\title{
Article \\ On-Site Identification of Pottery with pXRF: An Example of European and Chinese Red Stonewares
}

\author{
Gulsu Simsek Franci $^{1}$ (D) and Philippe Colomban ${ }^{2, *(D)}$ \\ 1 Surface Science and Technology Center (KUYTAM), Rumelifeneri Campus, College of Sciences, \\ Koç University, Rumelifeneri Yolu, Sariyer, Istanbul 34450, Turkey; gusimsek@ku.edu.tr \\ 2 MONARIS UMR8233, Sorbonne Université, Campus P. et M. Curie, CNRS, 4 Place Jussieu, 75005 Paris, France \\ * Correspondence: philippe.colomban@sorbonne-universite.fr
}

check for updates

Citation: Simsek Franci, G.; Colomban, P. On-Site Identification of Pottery with pXRF: An Example of European and Chinese Red

Stonewares. Heritage 2022, 5, 88-102. https://doi.org/10.3390/ heritage5010005

Academic Editor: Nicola Masini

Received: 7 December 2021

Accepted: 27 December 2021

Published: 29 December 2021

Publisher's Note: MDPI stays neutral with regard to jurisdictional claims in published maps and institutional affiliations.

Copyright: (C) 2021 by the authors. Licensee MDPI, Basel, Switzerland. This article is an open access article distributed under the terms and conditions of the Creative Commons Attribution (CC BY) license (https:// creativecommons.org/licenses/by/ $4.0 /)$.

\begin{abstract}
The invention of European hard porcelain, which aims at imitating kaolin-containing white paste of Chinese porcelain, had been started by the development of the technology of "red porcelain", so-called "Jaspisporzellan" by Johann Friedrich Böttger in the early-eighteenth century at Meissen (Saxony). The visual features of the earlier Böttger red stoneware were rather similar to the one produced in Yixing, China. The prominence of Böttger productions allowed the manufacturing to be expanded across Europe to different countries (Holland, England, France, etc.). In this study, the chemical characteristics of nine European unglazed objects produced in England, France, Russia, and Holland from the 17th to 19th century and 10 Chinese (unglazed or enameled) red stoneware have been studied by using an on-site characterization technique pXRF. The results were compared with the previous studies carried out on 25 unglazed, polished, and non-polished Böttger artefacts. This non-invasive, speedy technique allows a methodology to be created for distinguishing the technological differences related to the provenance and authenticity of the artefacts. The elemental measurements explicitly show the significant discrepancy of Dutch objects from the main group, which involves other European and Chinese ones. Both a Lambertus van Eenhoorn (Delft) statue and an Ary de Milde (Delft) teapot are distinguishable from other European red stoneware by the high content of iron and calcium and high content of titanium and potassium, respectively, found in their body compositions. An overall comparison was made between the measurements made at different times in order to evaluate the error range arising from the measurement procedure (e.g., energy resolution of other series of the same instrument model).
\end{abstract}

Keywords: stoneware; Europe; composition; pXRF; 17th-18th centuries; China; Ary de Milde; Böttger; Lambertus van Eenhoorn

\section{Introduction}

Even today, the identification of works of art mostly follows the senses of the connoisseur rather than a scientific point of view: the shape and texture of the object, color, aesthetics of the decor, weight in hand, sound after a slight shock, etc. It follows that the conclusion is highly subjective, if not an authoritative argument. The first scientific studies in history were performed at the beginning of the 18th century by the French scientist, Ferchault de Réaumur [1-4]. For a long time, at least until the 1950s, the method of analysis required the (partial) destruction of the pottery artwork [5], and even today, all the characterization techniques used remain micro-destructive and are carried out in the laboratory [6-8]. Since the beginning of the 2000s, the performance of mobile devices, namely Raman micro-spectrometer [9-16] and portable X-ray fluorescence (pXRF, Table 1) [15-38], has enabled on-site analyses of cultural heritage objects and materials in an attempt to answer the questions regarding the elementary and molecular composition and, thus, to apprehend questions relating to the place of production, authenticity, technology, exchanges, etc. The data in Table 1, which shows a survey published in a preliminary conference presentation [37], are certainly not exhaustive but show the incremental use of pXRF devices in 
the characterization of archaeological materials and cultural heritage objects. The intrinsic weaknesses of the method (weak positioning control on uneven surfaces, impossibility of measuring light elements $(\mathrm{B}, \mathrm{Li}, \mathrm{Na})$, the factor of energy resolution causing an interaction of elements (e.g., $\mathrm{Pb}$ and $\mathrm{As}$ ), wrong choice of in-built calibration modes, measurement from the top surface of a layered matter in which the in-depth penetration/absorption of X-ray photons depends on their energy, etc.) [31,32] initially led to a strong suspicion of the proponents of the alternative methods [21,22,30], more precise but micro-destructive [6-9] as to the accuracy of the pXRF measurements. However, the non-invasive nature of $\mathrm{pXRF}$ measurements leads to an increase in the use of the technique, and the measurement procedures make it possible to largely overcome the drawbacks of the devices.

Table 1 shows that, obviously, the most common use of pXRF in Cultural Heritage studies concern natural silicates (obsidian) and objects made of silicates (pottery, glass, enamels), although the reliability of the procedure is certainly better for metal alloys (fewer elements, better homogeneity for the probed volume, etc.).

Table 1. Number of pXRF papers retrieved from the database of Web of Science ${ }^{\circledR}$ (Clarivate Analytics) published between 2002 and 2019; some representative examples can be found in Refs. [13-34].

\begin{tabular}{lll}
\hline Object & Question & Number of Studies \\
\hline Obsidian and prehistoric tools & Origin, trade & 85 \\
Pottery (body) & Origin, technology & 48 \\
Glaze and enamels & Composition, technology & 22 \\
Paintings, frescoes & Colouring agents & 21 \\
Bronze & Composition & 18 \\
Rock art & Colouring agents & 8 \\
Glass beads & Origin, trade & 6 \\
Metal residues, slags & Technology & 5 \\
\hline
\end{tabular}

The importation of ceramic materials produced in China began in increasing quantities after the development of regular trade activities in the 17th century between the Far East and Europe by Portuguese traders, and then the Dutch, English, and to a lesser extent, French and Swedish East India companies [38,39]. Alongside the famous porcelains, which had monochrome or blue-and-white decorations, celadons in the view of jade, and red ceramics, called 'boccaro' or 'bucaro', were part of the shipments [9,40,41]. Ehrenfried Walther von Tschirnhaus and Johann Friedrich Böttger discovered a kaolin rich in iron oxide while investigating the raw materials that could lead to imitating Chinese (hardpaste) porcelains [41]. This discovery enabled them to produce, red stonewares, in the vernacular so-called, 'Jaspisporzellan' (analogically 'marbled' porcelain), similar to those produced in Yixing, China, first in Dresden and then in Meissen [35,36,41]. Such Chinese objects were present in the collection of Augustus II, (known as Augustus the Strong, Grand Elector of Saxony, King of Poland, Grand Duke of Lithuania), and Böttger made moulds from these objects to produce real replicas [41].

From a ceramic point of view, stoneware is very close to porcelain: the proportion of the vitreous phase is similar, and, therefore, the open porosity is low, ranging from about $9 \%$ to $3 \%(<1 \%$ for translucent porcelain) [42-46]. On the other hand, the dissolution of quartz grains is more limited. This very good densification makes it possible to polish stoneware such as semi-precious stones $[9,35]$, a technique known to J.F. Böttger, who was trained in lapidary techniques. The firing temperature is lower than that of porcelain (respectively, around 1150 to $1300{ }^{\circ} \mathrm{C}$ for stoneware and 1250 to $1450{ }^{\circ} \mathrm{C}$ for traditional porcelains) $[44,45]$ which gives the stoneware good mechanical properties despite the poor development of mullite needles [44-48].

Stoneware is usually obtained by using a stoneware clay ('argile grésante'). The characteristics of such clays have been identified in Normandy (Beauvaisie), Burgundy (PuisayeForterre), the region of Provins in France, but also in Germany (Rhineland, Westerwald), England (East-Anglia, Devon and Dorset), Czechia (Cheb), Holland (Delft), etc., by potters 
from at least the Middle Ages. Mineralogically, these 'clays' are made of kaolinites or halloisites (in fact, kaolinite is not a clay stricto sensu due to the absence of compensating cation in the inter-slab layer of the phyllosilicate, hence its greater refractoriness and lower plasticity) $[42,43]$ and illites-rich in organic materials such as humic acids; they are also called 'ball clays', 'plastic clays', or 'flint clays'. Illites highly contain iron, hence the reason of the more or less pronounced red color in almost all stoneware. Note that iron oxides react in reducing atmosphere (promoted by the organic matter) with fluxing oxides $\left(\mathrm{Na}_{2} \mathrm{O}, \mathrm{K}_{2} \mathrm{O}\right.$, $\mathrm{CaO}$ ) to form a liquid phase at temperatures lower than $800^{\circ} \mathrm{C}$, promoting the densification but also the formation of gas bubbles. Usually, these "clays" also contain "sand" (grains of quartz).

While European stonewares produced before the 17th century exhibit specific stylistic and color/aspect characteristics sufficient to identify them without any doubt, later productions, especially from the 18th century, share a common aesthetic that could make identification more difficult. Having shown its effectiveness, in particular in distinguishing the copies of Chinese models made by Böttger, the work carried out by mobile X-ray fluorescence (pXRF) on the 'boccaro' stonewares attributed to Meissen [32,33] was extended to objects attributed to other European production sites: England, Holland, Russia, and France.

A limited number of studies about the characterization of Böttger red stoneware have been published since the 1990s [9,35,36,49-55], particularly about the Delft and other European productions. With this study, the chemical characteristics of European (nine unglazed objects produced in England, France, Russia, and Holland) and Chinese (one enameled and 10 unglazed objects) red stonewares were defined by using an on-site characterization technique, pXRF, which allowed a methodology to be created for distinguishing the differences depending on the provenance and authenticity of the artefacts. The recent analyses were compared with the previously studied [35] 25 unglazed, polished, and non-polished objects, assigned to have been made by Böttger at Meissen, in addition to the reference materials published in the literature $[54,55]$. Technological differences, which depend on the provenance of the artefacts, were revealed as a result of this study.

\section{Experimental}

\subsection{Artefacts}

Figure 1 presents the analyzed objects described in detail in Table 2, belonging to the collections of the National Ceramic Museum founded by Alexandre Brongniart [56] at the beginning of the 19th century in Sèvres (now called Cité de la Céramique after merging with The National Sèvres factory founded in 1740 and established a few years after as a Royal factory). A total of 11 objects are attributed to China (Yixing), three objects to England, three to Holland, two to France, and one to Russia. The data obtained on these objects will be compared to the data obtained from 50 unglazed and 21 enamelled Böttger objects (actually including one Chinese, some fakes and modern copies), that were previously published $[35,36]$ The reader should refer to these papers to see the objects and their characteristics. The surface of most objects is left as sintered, except two of them, which are enamelled. Additionally, four or five of them have a surface smoothed/polished to give a gloss effect. Some have the marks indicated in Table 2. The absence of enamel on the surface prevents some of the weaknesses of the portable XRF instrument because the area analyzed is homogeneous and can be considered as of infinite thickness for the X-ray excitation. Furthermore, the authorization of the instrument placement in gentle contact with the artefact allows to reduce the distance of the X-ray pathway in free air (Figure 2).

Many selected objects entered the museum's collections in the 19th century, after being collected in 1837 by exchange with Dresden Museum Collections by the Director of the Sèvres Factory, Alexandre Brongniart, to constitute a technological and historical museum which brings together the most representative objects of ceramic art of every origin. This selection, according to the criterion of pedigree in arriving in the museum's collections at the beginning of the 19th century, is an important guarantee of the representativeness for many of the objects. 


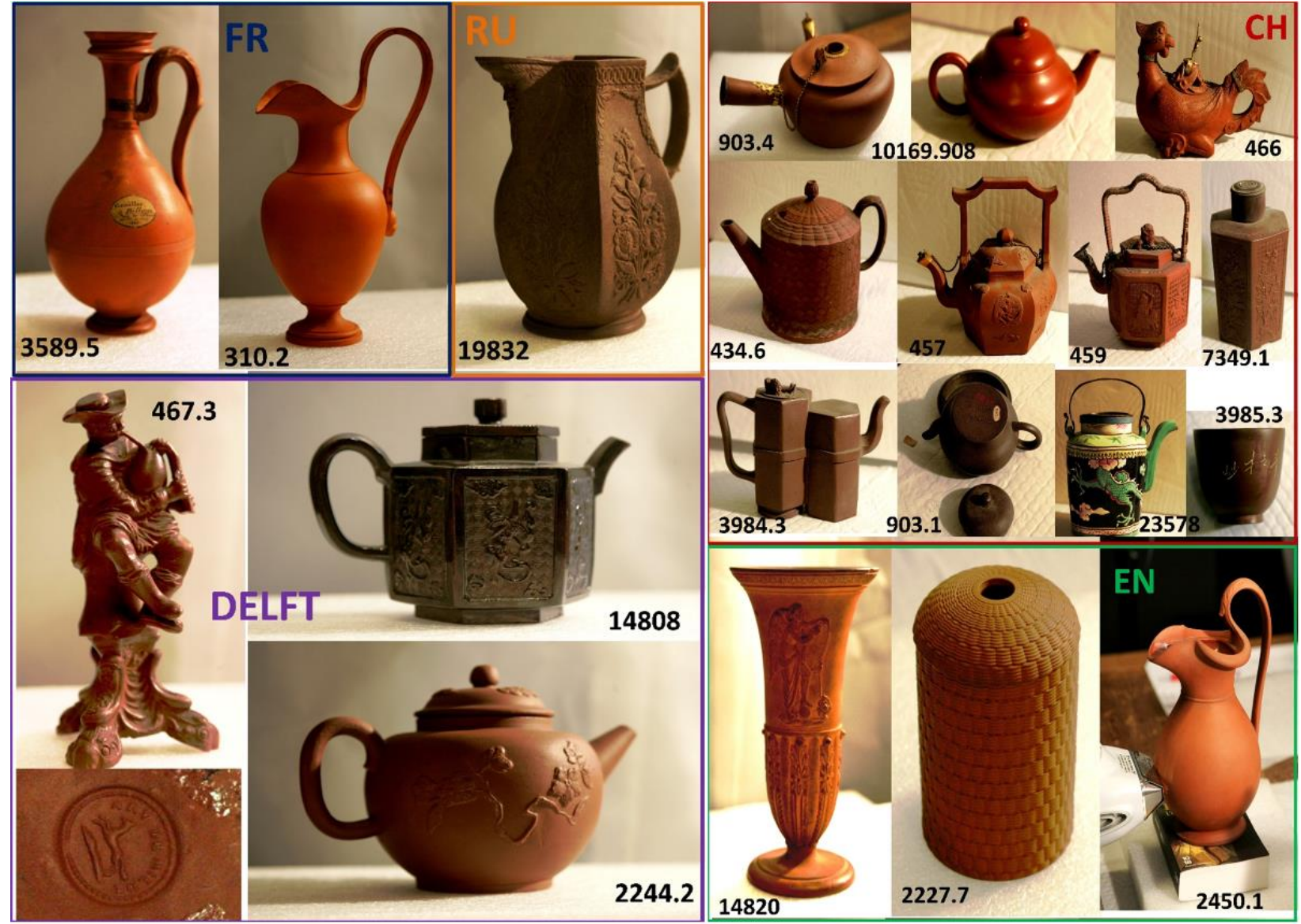

Figure 1. Objects examined in this study. See Table 2 for more information (FR: France; EN: Great Britain; RU: Russia, CH: China).

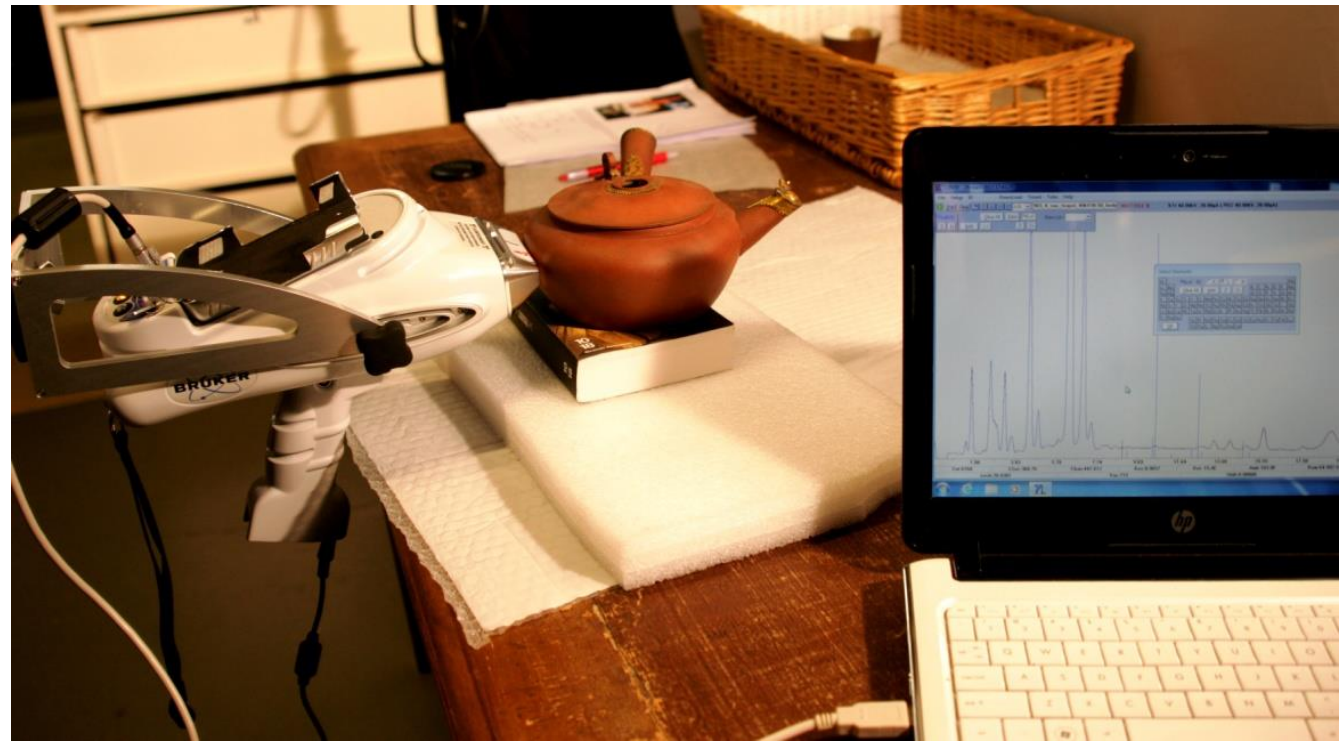

Figure 2. View of the measurement set-up. The XRF spectrum was evaluated after recording on the laptop screen. 
Table 2. Description of the objects studied and presented in Figure 1.

\begin{tabular}{|c|c|c|c|c|c|c|c|}
\hline $\begin{array}{l}\text { MNC } \\
\text { Code }\end{array}$ & Origin & $\begin{array}{l}\text { Approx. } \\
\text { Production } \\
\text { Date }\end{array}$ & $\begin{array}{l}\text { Object } \\
\text { (Factory) }\end{array}$ & $\begin{array}{l}\text { Dimension } \\
(\mathrm{cm})\end{array}$ & Surface & Couleur & $\begin{array}{c}\text { Remarks, } \\
\text { Date of Entrance in } \\
\text { the Collection }\end{array}$ \\
\hline 903.4 & \multirow{12}{*}{$\begin{array}{l}\text { China } \\
\text { (Yixing) }\end{array}$} & 18th c. & Teapot & $\begin{array}{c}\mathrm{H}: 9.9 \\
\mathrm{~L}: 18.9 \times 21.5\end{array}$ & Unpolished & Brown-red & 1826 (from Salé Coll.) \\
\hline $10,169.908$ & & 19th c. & Teapot & $\begin{array}{c}\text { H:5.6; } \\
\text { D:6; L:8.9; }\end{array}$ & Glossy & Red & $\begin{array}{l}\text { Expected to be a copy } \\
\text { of a teapot made by } \\
\text { Hui Mengshen, } \\
1894 \text { (Coll. Frandon } \\
\text { and de Voltais) }\end{array}$ \\
\hline 466 & & 18th c. & $\begin{array}{l}\text { Teapot } \\
\text { (feasan) }\end{array}$ & $\begin{array}{c}\text { H:11.4; } \\
\text { D:6.5;L:13.9 }\end{array}$ & Unpolished & Brown-red & \multirow[t]{4}{*}{1806} \\
\hline 434.6 & & & Teapot & $\begin{array}{c}\text { H:16.6; } \\
\text { D:11.6; L:18.6 }\end{array}$ & Unpolished & Brown-red & \\
\hline 457 & & Unknown & Teapot & $\begin{array}{c}\text { H:16.6; } \\
\text { D:11.6; L:18.6 }\end{array}$ & Unpolished & Brown-red & \\
\hline 459 & & Unknown & Teapot & $\begin{array}{c}\text { H:16; } \\
\text { D:9.8; L:14.8 }\end{array}$ & Unpolished & Brown-red & \\
\hline 7349.1 & & Unknown & Tea box & $\begin{array}{c}\text { H:17.4; } \\
\text { D:10;L:11.7; }\end{array}$ & Unpolished & $\begin{array}{l}\text { Dark- } \\
\text { brown }\end{array}$ & $\begin{array}{l}\text { Manufactured in Hle } \\
\text { Sing or Y-Ching, } 1878\end{array}$ \\
\hline 3984.3 & & $\begin{array}{l}\text { 18th } \\
\text { or 19th c. }\end{array}$ & Teapot & $\begin{array}{c}\mathrm{H}: 10.9 ; \\
\mathrm{D}: 6.7 ; \mathrm{L}: 17.2\end{array}$ & & $\begin{array}{l}\text { Dark- } \\
\text { brown }\end{array}$ & 1849 \\
\hline 903.1 & & unknown & Teapot & $\begin{array}{l}\text { H: 6.5; D:7.4; } \\
\quad \text { L:10.4; }\end{array}$ & Glossy & $\begin{array}{l}\text { Dark } \\
\text { brown }\end{array}$ & \\
\hline 23,578 & & 19th c. & Teapot & $\begin{array}{l}\text { H:14.8; } \\
\text { D:12.6; } \\
\text { L:18.2; }\end{array}$ & $\begin{array}{l}\text { Enamelled } \\
\text { decor }\end{array}$ & $\begin{array}{l}\text { Many } \\
\text { colours }\end{array}$ & 1974 \\
\hline 3985.3 & & Unknown & Tea cup & $\begin{array}{l}\text { H:6; D:7.5 } \\
\text { D (base):3.7 }\end{array}$ & $\begin{array}{l}\text { Interior } \\
\text { enamelled } \\
\text { in white }\end{array}$ & $\begin{array}{l}\text { Dark- } \\
\text { brown }\end{array}$ & $\begin{array}{c}\text { Mark: made at } \\
\text { Chang-ai, Kiang-nan, } \\
1849\end{array}$ \\
\hline $\begin{array}{l}\text { SC 10- } \\
169-1056 \\
*\end{array}$ & & & Teapot & $\mathrm{H}:: \sim 10$ & Unpolished & Light red & Assigned as Yixing \\
\hline SC $462 *$ & Germany & & Teapot & $\mathrm{H}: 9.4 ; \mathrm{D} 13$ & Unpolished & Red & Assigned to Böttger \\
\hline 14,820 & England & 19th c. & $\begin{array}{l}\text { Horn-shaped } \\
\text { vase } \\
\text { (Isleworth) }\end{array}$ & $\mathrm{H} \sim 20$ & Glossy & Red & $\begin{array}{c}1908 \\
\text { (from de Grollier Coll.) }\end{array}$ \\
\hline 2227.7 & & $1836 ?$ & $\begin{array}{l}\text { Candlestick } \\
\text { (J. Wedgwood } \\
\text { Factory) }\end{array}$ & $\mathrm{H} \sim 12$ & Unpolished & Red-brown & $\begin{array}{c}1836 \\
\text { (from M. Wood Coll., } \\
\text { Burslem) }\end{array}$ \\
\hline 2450.1 & & $1837 ?$ & $\begin{array}{l}\text { Decoction pot } \\
\text { (J. Wedgwood } \\
\text { Factory) }\end{array}$ & $\mathrm{H}: 25$ & & Red & $\begin{array}{c}1837 \\
\text { (from I. Taylor Coll.) }\end{array}$ \\
\hline 3589.5 & France & Unknown & Burette & $\mathrm{H} \sim 20$ & Glossy & Red & $\begin{array}{c}1846 \text { (from M. Le Coq } \\
\text { Coll.) }\end{array}$ \\
\hline 310.2 & & 1790 & Ewer & $\begin{array}{l}\text { H:19.3; D:8; } \\
\text { L:11.4; }\end{array}$ & Glossy & Red & 1802 \\
\hline 19,832 & Russia & 1852 & $\begin{array}{c}\text { Ewer } \\
\text { (Mejigorie } \\
\text { Factory, Kiev) }\end{array}$ & $\mathrm{H}: 16$ & Unpolished & Brown-red & 1938 \\
\hline 467.3 & $\begin{array}{l}\text { Holland } \\
\text { (Delft) }\end{array}$ & $\begin{array}{l}\text { First quarter } \\
\text { of 18th c. }\end{array}$ & $\begin{array}{l}\text { Doedelrakspeler } \\
\text { statuette } \\
\text { (bagpiper), } \\
\text { (Lambertus } \\
\text { van Eenhoorn } \\
\text { mark) }\end{array}$ & $\begin{array}{l}\mathrm{H}: 17 \\
\mathrm{~L}: 9\end{array}$ & Glossy & Red & $\begin{array}{c}1806 \\
\text { In the past assigned to } \\
\text { a Böttger copy }\end{array}$ \\
\hline
\end{tabular}


Table 2. Cont.

\begin{tabular}{|c|c|c|c|c|c|c|c|}
\hline $\begin{array}{l}\text { MNC } \\
\text { Code }\end{array}$ & Origin & $\begin{array}{l}\text { Approx. } \\
\text { Production } \\
\text { Date }\end{array}$ & $\begin{array}{l}\text { Object } \\
\text { (Factory) }\end{array}$ & $\begin{array}{l}\text { Dimension } \\
(\mathrm{cm})\end{array}$ & Surface & Couleur & $\begin{array}{c}\text { Remarks, } \\
\text { Date of Entrance in } \\
\text { the Collection }\end{array}$ \\
\hline 14,808 & & 1680-1708 & $\begin{array}{c}\text { Teapot } \\
\text { (De } \\
\text { Grecroonde } \\
\text { Factory- Ary } \\
\text { de Milde mark) }\end{array}$ & H:10; L:14; & Glazed & Black & \\
\hline 2244.2 & & 1680-1708 & $\begin{array}{c}\text { Teapot } \\
\text { (De } \\
\text { Grecroonde } \\
\text { Factory- Ary } \\
\text { de Milde mark) }\end{array}$ & $\begin{array}{l}\mathrm{H}: 11.5 ; \\
\mathrm{L}: 17\end{array}$ & Glossy & Brown-red & $\begin{array}{l}1836 \text { (from Dresden } \\
\text { Coll.) }\end{array}$ \\
\hline
\end{tabular}

* The images of these objects are shown in [35].

\subsection{Portable X-ray Fluorescence ( $p X R F$ )}

$\mathrm{X}$-ray fluorescence spectroscopy analysis was performed using a Bruker Tracer III-V (Bruker AXS, Karlsruhe, Germany) portable system equipped with a rhodium (Rh) target $X$ ray tube that was operated at $40 \mathrm{kV}, 20 \mu \mathrm{A}$ (for high-Z elements) and $15 \mathrm{kV}, 44 \mu \mathrm{A}$ (for low-Z elements) to identify the network modifiers and coloring/gilding agents found on the glaze, as previously described $[35,36]$. A vacuum pump was used during the measurement at a lower voltage to enhance the detection of low-Z elements (from aluminum to titanium). The beam size at the surface was roughly $0.15 \mathrm{~cm}^{2}$.

The measurements were carried out on at least three different areas of the body. The results are reported as the mean values of all of the individual point analyses done on each object. The raw data, which represent the elemental composition of the objects' bodies, are given in the Supplementary Material. For a qualitative evaluation purpose, $\mathrm{K} \alpha$ lines of $\mathrm{Al}$, $\mathrm{Si}, \mathrm{K}, \mathrm{Ca}$, transition metal elements ( $\mathrm{Ti}, \mathrm{Cr}, \mathrm{Mn}, \mathrm{Fe}, \mathrm{Cu}, \mathrm{Zn}$ ) and trace elements ( $\mathrm{Rb}, \mathrm{Sr}, \mathrm{Y}$, $\mathrm{Zr}$ ), as well as the $\mathrm{L}$ spectral lines of lead $(\mathrm{Pb})$, were taken into consideration. Silicon is the major element of both glaze and body layers ( $\mathrm{Si}$ counts are measured between 10.000 (min.) and 40.000 (max.)). In order to compare current and previous measurements, the mean area counts of most of the elements are normalized by those of $\mathrm{Si}$ in addition to eliminate the effect of the varied distance of the instrument tip and analysis surface.

The previous study in 2012 was only carried out on Böttger and Chinese stonewares to distinguish the technological differences of these two production centres. Thereafter, in 2013, we increased the number of production places (France, England, low countries, and Russia) but also re-analyzed two objects already studied with another series of the same XRF instrument (Bruker Tracer III-V) in order to evaluate the reliability of the procedure (measurement and/or associated data treatment) on the results.

\subsection{Evaluation of the $p X R F$ Data}

Bruker Tracer III-V pXRF spectrometers do not contain built-in analytical modes (e.g., Soil, Mining, Rare Earths, etc.) like the later-generation pXRFs $[31,32,57,58]$. These modes operate at different voltages, e.g., for Mining mode double excitation at $15 \mathrm{kV}$ and $40 \mathrm{kV}$, and for Alloy mode only one excitation at $40 \mathrm{kV}$. At the factory, these analytical built-in modes were created after performing the calibration measurements of proper standards [31,59]. The data obtained with Tracer models of Bruker were treated after recording the spectrum (Figure 3), either by interpreting the mean of area counts [35,36] or using an external calibration method. For ceramic materials, the calibration of Mud Rock, which is Mother Nature's fine grain soil, was used. Dr. Harry Rowe at the UT Bureau of Economic Geology selected those that cover an extensive range of elements (from low- $\mathrm{Z}$ ( $\mathrm{Na}$ ) to high- $\mathrm{Z}$ ( $\mathrm{Pb}$ in our case) elements) found in natural soil and ceramic materials. The calibration files, MA1 (for major elements) and TR2 (for trace elements), were provided for each instrument by the application scientists of Bruker Company. These files were re-formulated depending 
on the energy resolution of each instrument, even though they have the same model. The measurements were carried out in 2012 with a Tracer that had an energy resolution of $210 \mathrm{eV}$ and the measurements in 2013 with an energy resolution of $180 \mathrm{eV}$. Since the XRF method cannot measure $\mathrm{C}, \mathrm{O}$, and $\mathrm{H}$, the weight percentage of the elements does not add up to 100 percent. Instead of normalizing the elements' concentrations to 100, we normalized the data by dividing the weight percent of Si content in each measurement, silicon being present in all analyzed spots. Each color is referred to a different production center (labels in red, China; dark yellow, Böttger; grey, Delft; green, England; pink, Russia; blue, France). Through this evaluation procedure, we were able to compare both 2012's and 2013's measurements carried out with different series of the same instrument. Additionally, the results of the reference materials extracted from the literature were shown with the labels in light-yellow color in the figures of scattering plots. Stoneware has the advantage of being homogeneous for the spatial area and volume probed by the measurement. Indeed, the accelerating voltage referring to the energy of the incident radiation stimulating the emission of radiation from the sample affects which elements can be excited and measured, as well as the probed volume. In the case of the use of a target material (for example, in a $\mathrm{Rh}$ tube) the accelerating voltage needs to be 1.5-2 times the absorption edge energy of Rh. $\mathrm{Rh} \mathrm{K}$ Lines is $23.224 \mathrm{keV}$, so a voltage range of $35-45 \mathrm{kV}$ is required. For low- $\mathrm{Z}$ elements, the highest absorption edge energy would be $6.537 \mathrm{keV}(\mathrm{Mn})$, which requires the use of a $13 \mathrm{kV}$ accelerating voltage (Figure 3).

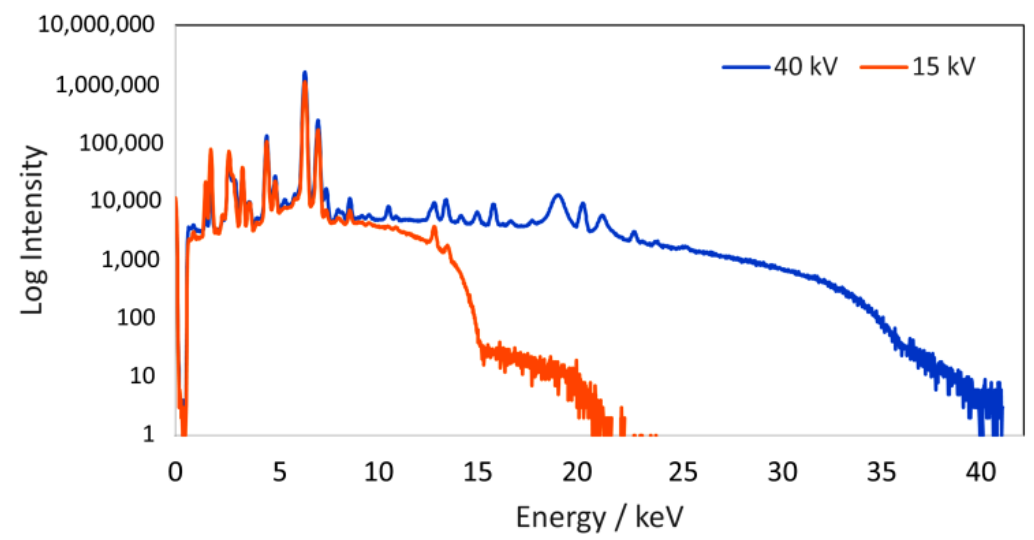

Figure 3. Comparison of pXRF spectra recorded in the same spot with 15 and $40 \mathrm{kV}$ accelerating voltages (MNC 10,169.908).

The drawback will be that, for a higher accelerating voltage, a higher background will form [60]. Therefore, it is important to properly correlate the accelerating voltage and filter selection during the measurement. The sample matrix and density of the materials will also affect the detection capability. For this reason, the measurement of major, low- $Z$ elements ( $\mathrm{Al}, \mathrm{Si}, \mathrm{Mg}, \mathrm{K}, \mathrm{Ca}$ ) is made on the top surface layer (a few microns of thickness), although the determination of heavy elements, such as $\mathrm{Pb}$ and $\mathrm{Sn}$ made up to a few hundred microns. The similarity of the composition of the artefacts allowed us to create a comparison between the objects. Moreover, the same measurement and data evalaution procedures have been applied. Statistica 13.5 (TIBCO Software Inc., Palo Alto, CA, USA) was used for drawing the scattering plots. 


\section{Results}

3.1. Nature of Red Porcelain/Stoneware and Expected Raw Materials and Compositional Characteristics

We need first to recall which raw materials are required to produce stoneware in order to highlight the most important parameters regarding elemental composition.

According to the famous book of Brongniart [56], the paste of stoneware is produced from a 'ball clay' (e.g., a very plastic clay). Alternatively, stoneware can be prepared by mixing the China clay (2-24 wt\%, rich in kaolinite or halloysite), ball clay (24-48 wt\%, rich in illite), and flint (2-43 $\mathrm{wt} \%$, a rather pure silica stone). A small amount of marl (mixture of clay and calcareous matter) or pegmatite ('grauen', a mixture of quartz and feldspar/plagioclases) can also be added. By comparison, the typical composition of a porcelain paste contains $50 \mathrm{wt} \%$ kaolin, $25 \mathrm{wt} \%$ feldspar, and $25 \mathrm{wt} \%$ quartz. Note that 5 to $8 \mathrm{wt} \% \mathrm{Fe}_{2} \mathrm{O}_{3}$ are required to obtain the red color. The precise composition and raw materials used by Böttger are not known, but some information has been extracted from ancient documents by Goder et al. [41]. Arcanist Johann Friedrich Böttger, in association with Ehrenfried Walther von Tschirnhaus, a famous chemist and glassmaker who designed the lenses of a solar furnace that was able to melt kaolin, searched for refractory clays in Saxony and around to prepare artefacts equivalent to imported China and developed hightemperature firing procedures. Böttger identified red refractory earths, namely 'kaolins' extracted at Okrilla, or close to Aue (Rote Sankt Andreas, Weisserden); the latter is a mixture of kaolin, quartz, mica and hematite. Furthermore, the other clays used, extracted from Zwickau, Waldenburg and Colditz in Saxony and the clay in Troschenreuth, close to Nürnberg (Bavaria), contain feldspar and/or shale. It is not established if quartz or quartzite was used. The flux used at Meissen was made of alabaster (gypsum), and/or calcite ('spath').

Scholars noted that the Chinese red stoneware exhibited a surface more corrugated than that of Böttger's artefacts. The optical examination of fracture or section shows that the quartz grains are actually larger in the Chinese paste in comparison with Böttger stoneware. The porosity ranges from $6 \%$ to $8 \%$. The large amount of mullite measured in Meissen porcelain production, higher than in Chinese homologs, is related to the different composition (Meissen: $\sim 30 \%$ wt $\mathrm{Al}_{2} \mathrm{O}_{3}$ vs. $\sim 20 \%$ wt for Chinese porcelain $[45,61]$ ) and (expected) firing temperatures, ca. $1200-1300{ }^{\circ} \mathrm{C}$ in China, $\sim 1450{ }^{\circ} \mathrm{C}$ at Meissen $[9,41,61]$. Previous pXRF analyses carried out on stonewares attributed to Böttger (Meissen factory, Saxony, Germany) production showed that the content of $\mathrm{K}$ versus $\mathrm{Ca}$, and Ti versus Fe were very effective in distinguishing Böttger's productions from Chinese models [35,36,41]. The elements, potassium and calcium, are primarily related to the flux content, although iron and titanium are associated with the secondary phases, which color the 'earths' in red, for instance, the hematite mineral present in Okrilla and Aue rocks. Hematite, as well as brookite, are nonstoichiometric compounds with more or less important substitution of Fe atoms by $\mathrm{Ti}$ or $\mathrm{Al}$.

\subsection{Elements Associated with Fluxes}

The comparison of the $\mathrm{K}_{2} \mathrm{O} / \mathrm{Fe}_{2} \mathrm{O}_{3}, \mathrm{TiO}_{2} / \mathrm{Fe}_{2} \mathrm{O}_{3}, \mathrm{MnO} / \mathrm{Fe}_{2} \mathrm{O}_{3}$, and $\mathrm{PbO} / \mathrm{Fe}_{2} \mathrm{O}_{3}$ ratios from the compositions measured by PIXE led Swann and Nelson to identify three groups among 16 objects attributed to Böttger [53]. Our previous measurements on 71 artefacts $[35,36]$ show two not very distant groups for the Meissen productions by Böttger and 20th century replicas of the same manufacture, while the origin of objects characterized by a lower level of iron and titanium was questioned and assigned to copy/fake. Unglazed, polished and non-polished objects were selected for the interpretation of the new results carried out on red stonewares of different production centres. In summary, previous pXRF analyses of Böttger stoneware $[35,36]$ pointed out that rubidium and strontium, which are the natural impurities of (earth-)alkali, are also characteristic for the comparison of provenance determination in relation to the use of different fluxes containing either potassium or calcium. Figure 4 compares pXRF spectra recorded on two Delft stonewares and a Yixing 
production. In most cases, compositional differences are too limited to identify visually, but in rare cases, characteristic peaks-in this case, peaks of $\mathrm{Ca}, \mathrm{Mn}, \mathrm{Pb}$, and $\mathrm{Rb}$-allow the elemental composition of different productions to be differentiated.

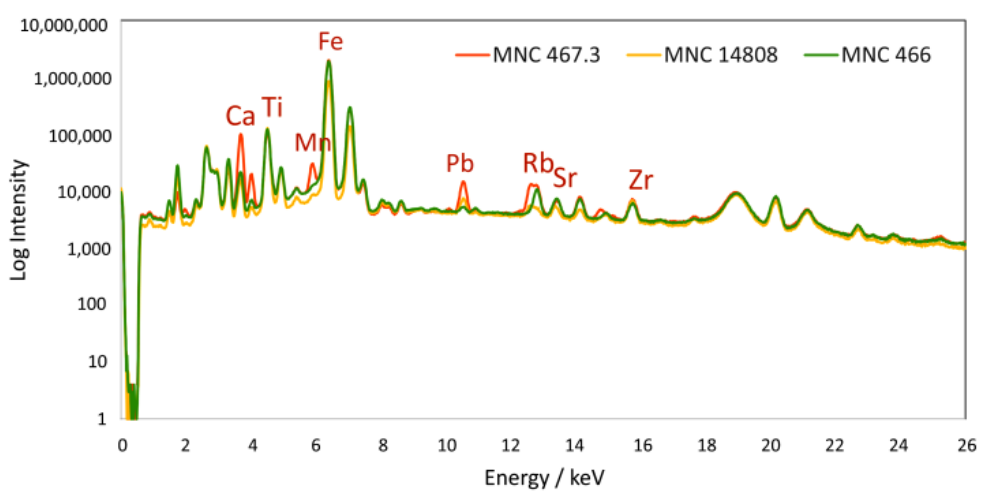

Figure 4. Comparison of pXRF spectra recorded under $40 \mathrm{kV}$ accelerating voltage on MNC 467.3 (bagpiper, Lambertus van Eenhoorn mark, Delft), MNC 14,808 (teapot, Ary de Milde mark, Delft) and MNC 466 (teapot, Yixing, China) artefacts. Binary scatter plots of K versus Ca (Figure 5), normalized by $\mathrm{Si}$, explicitly show the discrepancy of Delft productions from the other red stonewares produced in China and Europe. Moreover, the ewer inv. MNC 310.2 assigned to France has a similar amount of potassium (K/Si: 0.2) in comparison with the teapot of Ary de Milde, Delft (MNC 2244.2). The minimum amount of potassium (K/Si: 0.04) and a small amount of calcium $(\mathrm{Ca} / \mathrm{Si}: \sim 0.08-0.10)$ are evidenced in Wedgwood productions.

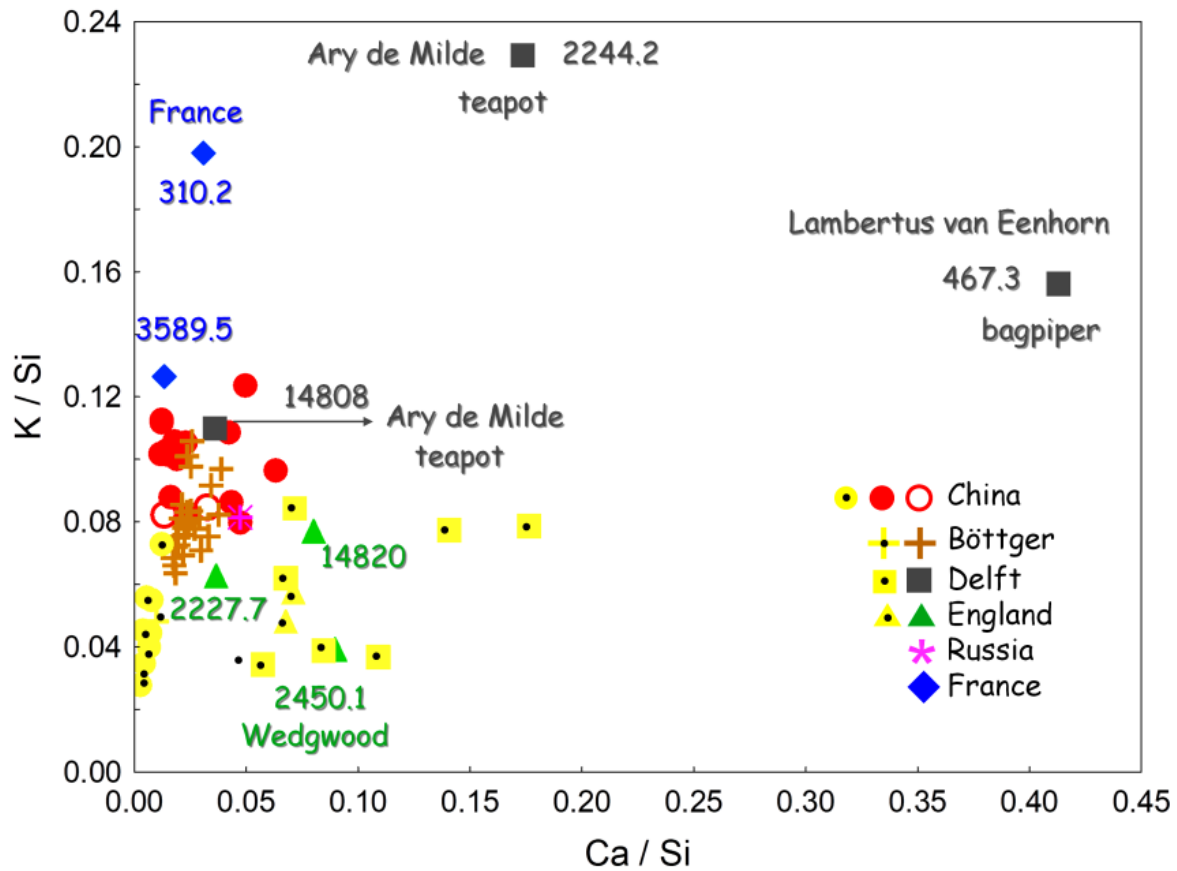

Figure 5. Scatter plots of the old (plus sign attributed to Böttger analyses carried out in 2012 and blank circle to the Chinese ones) and new data (solid circle: China, square: Delft, triangle: England, radial: Russia, and rhomboid: France) compared to the reference data (labels in yellow color) [51,52] regarding fluxing elements (K versus Ca normalized by $\mathrm{Si}$ ) found in the composition of red stoneware.

The binary and ternary scatter plots (shown in Figures 5-7) confirm the comparability of the previous (2012) and later (2013) measurements after evaluating the data according to the Mud Rock calibration criteria. A comparison of the data collected on the Böttger 'Jaspisporzellan' with those obtained on the other European productions shows the very 
low dispersion of the element content for Meissen production; the $\mathrm{K}$ content is constant $(\mathrm{K} / \mathrm{Si} \sim 0.3+-0.1)$, although for European red stoneware the K/Si ratio varies between $\sim 0.2$ and 1.2. The $\mathrm{Ca} / \mathrm{Si}$ ratio is more scattered ( $\sim 0.07$ to 0.25$)$ but remains much smaller than other European artefacts (0.1 to 0.8 ). However, The K/Ca ratio does not make it possible to differentiate Meissen stonewares from English stonewares-note the artefact with the Ary de Milde mark shows a $\mathrm{Ca} / \mathrm{Si}$ ratio of $\sim 0.4$.
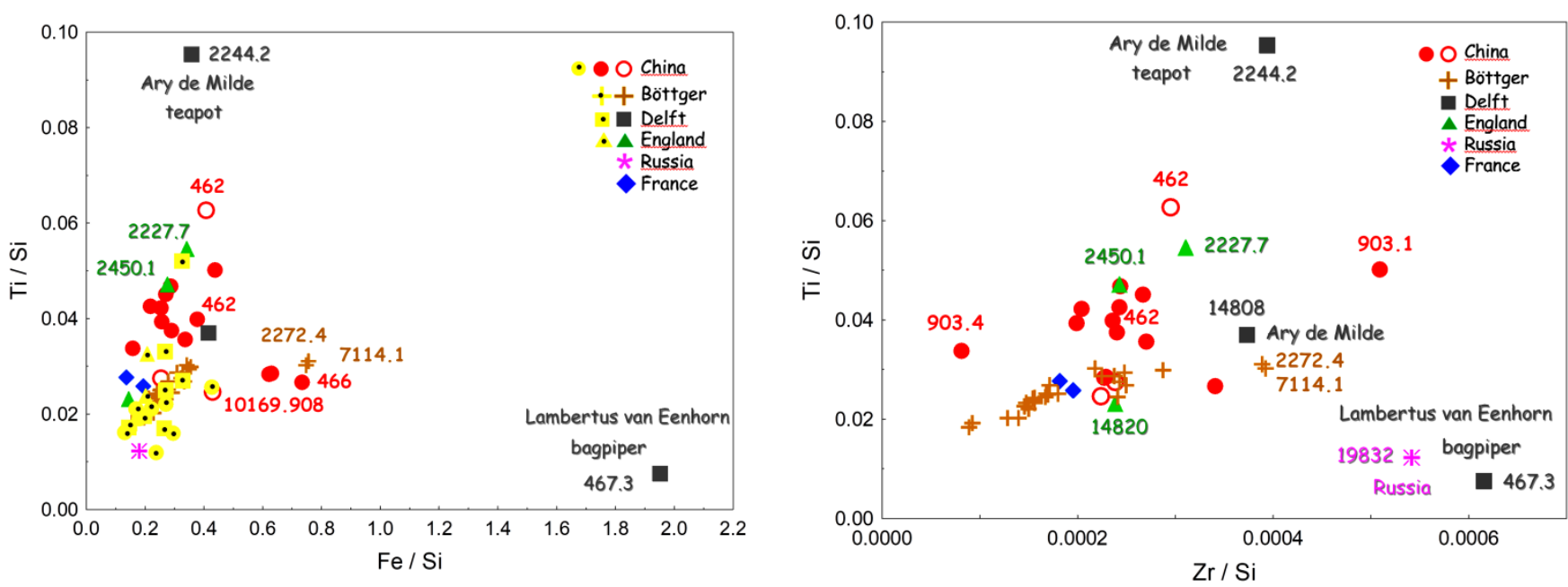

Figure 6. Comparison of the old (plus sign attributed to Böttger analyses carried out in 2012 and blank circle to the Chinese ones), new, and reference data regarding $\mathrm{Ti}$, $\mathrm{Fe}$, and $\mathrm{Zr}$ content measured on European and Chinese red stonewares compared with Meissen Böttger. See the caption of Figure 3 for the symbols.

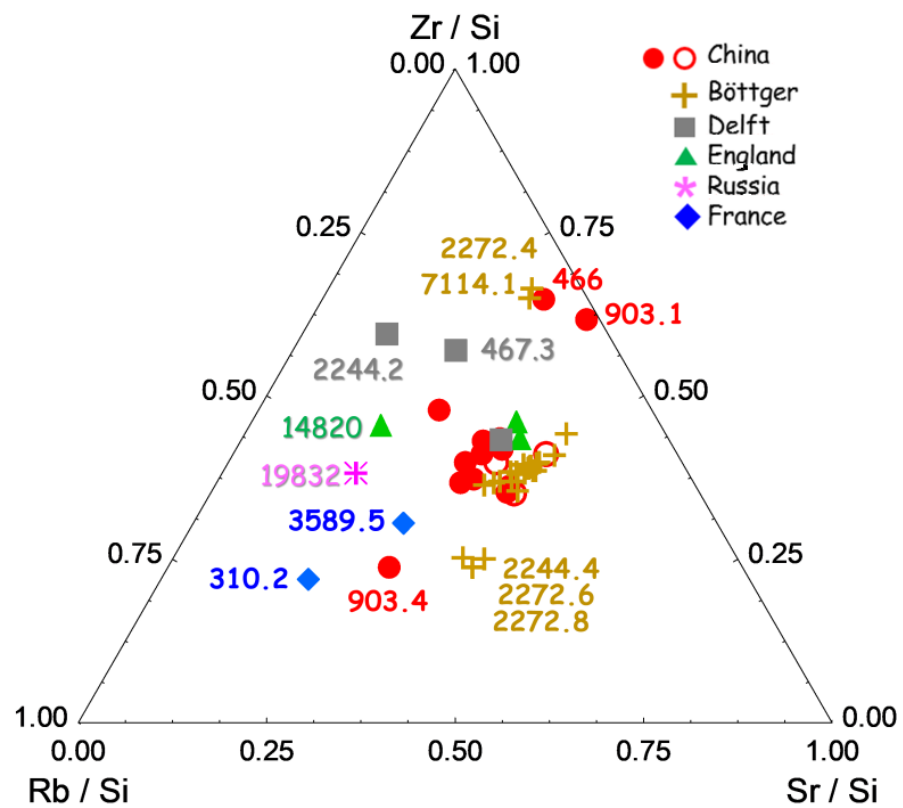

Figure 7. Ternary diagram of trace elements $(\mathrm{Zr}, \mathrm{Rb}$, and $\mathrm{Sr})$ distribution in the body composition.

The main difference among Böttger productions has arisen from the distribution of trace elements ( $\mathrm{Rb}$ and $\mathrm{Sr}$ ) in their body composition. This distinction was previously evidenced in the first study of Böttger characterization [35]. The two Sevres objects (MNC 2272-4 and MNC 7114-1) were assigned as a Böttger production in the old museum inventory, but have been re-assigned stylistically to Chinese production by the curators [35]. This stylistic attribution was confirmed by pXRF analyses, which showed a similarity in 
the chemical composition of a series of Chinese stoneware. The relatively close similarity between Meissen, Yixing, and most of the Delft productions for the major fluxing elements can be related to the selection of clays with rather similar ceramic properties (plasticity, iron and flux content, and sinterability) required for a firing in a similar temperature range and, hence, their relatively similar composition.

\subsection{Elements Associated with Stable Minerals}

Hematite, anatase, and rutile are commonly identified by Raman spectroscopical studies of porcelains. However, these minerals, already present in many raw materials [35,36], are sufficiently stable to not be (completely) dissolved during firing cycles. Zircon is also a minor phase of many raw materials (quartz, pegmatite, etc.) and does not react during firing cycles. Taking into account the ratio of Ti versus $\mathrm{Fe}$, normalized by $\mathrm{Si}$, also demonstrates the homogeneity of Böttger's data (Figure 6), except for two objects: MNC 2272-4 and MNC 7114-1. These two objects, the vases, were assumed to be Böttger productions, but the chemical composition of the body corresponds more to a Chinese production. Figure 6 also demonstrates the similarity of these objects to a Chinese artefact, MNC 466 (Table 1), attributed to the Yixing production. The other artefacts of Böttger and some of Chinese objects form a second group which have lower amounts of Fe by revealing a technological relationship. However, when the data are more focused on these two productions by discarding European red stonewares, the ratio identifies in distinguishing Meissen artefacts from Chinese stonewares, as well as from modern copies or fakes [35,36]. Ti/Si vs. Fe/Si biplot clearly identifies the Delft productions other than Ary de Milde artefacts. However, modern Russian (Kiev) artefacts exhibit low Fe content. Unfortunately, the distribution of data on English and Chinese productions overlaps.

\subsection{Most Pertinent Element for the Differentiation of the Provenance}

Comparison of Böttger and Chinese artefacts pointed out that $\mathrm{Rb} / \mathrm{Si}$ and $\mathrm{Sr} / \mathrm{Si}$ ratios, and also $\mathrm{Zr}$ content (Figure 7), are the most effective characteristic to discriminate the artefacts, as previously noted for the differentiation of genuine and fake Meissen artefacts $[35,36]$. The $\mathrm{Zr} / \mathrm{Si}-\mathrm{Rb} / \mathrm{Si}-\mathrm{Sr} / \mathrm{Si}$-plotted ternary diagram clearly distinguishes the productions among Russia, France, and Delft (Ary de Milde and Lambertus van Eenhoorn).

The main group of Chinese artefacts, which was assigned to the productions of Yixing factories, is clustered within the group of Böttger and Chinese artefacts previously studied in 2012. Exceptionally, a series of Chinese (MNC 466, MNC 903.1) and Böttger (MNC 2272.4, MNC 7114.1) objects are observed with the higher amount of $\mathrm{Zr}$ and lower amount of $\mathrm{Sr}$ and $\mathrm{Rb}$. However, the Chinese teapot, MNC 903.4, is located separately from the other Chinese artefacts because it contains a very low amount of Sr and Zr. The few artefacts produced in Russia are rich in trace elements $\mathrm{Rb}, \mathrm{Sr}$, and $\mathrm{Zr}$. The bagpiper with a Lambertus van Eenhoorn mark and the glossy teapot with an Ary de Milde mark, produced in the factory of De Grecroonde (Delft), differentiate materially from the main group, and especially from the other glazed teapot which is assumed to be produced in the same factory, by Ary de Milde also, according to the content of trace elements. The chemical differences in the raw materials used in the body of French and Russian productions also reveal the discrepancy of the provenance (i.e., raw materials) of the objects.

\section{Discussion}

On-site measurements clearly show the technological differences of Delft productions from the other European and Chinese productions because they are richer in both $\mathrm{Ca}$ and $\mathrm{K}$ as fluxes, which allow them to be fired at lower temperatures and, thus, at lower costs. Therefore, the use of these fluxes led to a high level of commercial success to be achieved). Moreover, they also show a discrepancy where the variation of the body composition is largely varied. Indeed, at the end of the 17th and beginning of the 18th centuries, three Dutch potters, Lambertus Cleffius, the owner of the Metal Pot, Lambertus van Eenhoorn, and Ary de Milde, were working to produce red stoneware. However, the use of different 
raw materials in the same region was not expected until the chemical compositions were identified with pXRF. Additionally, the detection of trace elements reveals the importance of more precise measurements, since the literature only shows the results of major elements, such as $\mathrm{Fe}, \mathrm{Ti}, \mathrm{Ca}$, and $\mathrm{K}[54,55]$, which cannot distinguish provenance differences. In addition to Dutch productions, Wedgwood artefacts reflect a change in the content of the body, which may reflect a transition from old (earlier-19th century) to recent (later-19th century) productions by diminishing the amount of potassium. The same case may be valid for French artefacts, depending on either the production period or the factory. It should be interesting to relate these evolutions of the technologies with increasing mass production and economic constraints.

The analyses observed the influence of Chinese red stoneware technology's impact on European ceramic makers in the 18th and 19th centuries. Most of them were influenced aesthetically, but Böttger used not only the same style but also rather similar technology by mixing similar raw materials.

\section{Conclusions}

The calibration and normalization procedures demonstrated the validity of old and recent analyses were carried out with the same model but a different series of pXRF instrument. The interpretation of the data is as essential as the measurement process. Additionally, the analyses carried out with our pXRF instrument were comparable with the old measurements carried out at the laboratory with highly sensitive instruments (e.g., ion beam techniques, energy dispersive fluorescence system). Lastly, the detection of trace elements ( $\mathrm{Rb}, \mathrm{Sr}, \mathrm{Zr}$ ) was achievable using an on-site, non-invasive technique. This study aimed to identify the differences regarding the raw materials used by different potters who worked in different countries (Russia, Holland, England, France, Germany, and China) in the 18th and 19th centuries. The analyses showed that Böttger was influenced directly by the technology of Chinese productions and used a similar recipe for making red stoneware. However, Delft productions differ locally and internationally from the other factories in terms of flux selections rich in calcium and/or potassium, and these characteristics could have been a determining factor for the low production costs and the success of these productions.

Supplementary Materials: The following supporting information can be downloaded at: https: / / www.mdpi.com/article/10.3390/heritage5010005/s1, Table S1: The amount (wt\%) of the elements extracted from the calibration of Mud Rock after recording the raw data.

Author Contributions: Conceptualization, G.S.F. and P.C.; methodology, G.S.F. and P.C.; validation, G.S.F. and P.C.; investigation, G.S.F.; resources, G.S.F. and P.C.; writing-original draft preparation, G.S.F. and P.C.; writing-review and editing, G.S.F. and P.C. All authors have read and agreed to the published version of the manuscript.

Funding: This research received no external funding.

Data Availability Statement: Provided as Supplementary Materials.

Acknowledgments: The authors acknowledge Viviane Mesqui and Laurence Tilliard (Curators), as well as Véronique Milande (former Head of Restoration Office,) and Jean-Claude Duvic (Restoration Office) for many discussions for the access and provision of the objects of Cité de la Céramique Collection and the organization of the analytical measurements.

Conflicts of Interest: The authors declare no conflict of interest.

\section{References}

1. Ferchault de Réaumur, R.A. Observations sur la Matière Qui Colore des Perles Fausses et sur Quelques Autres Matières Animales D'une Semblable Couleur, à L'occasion de Quoi on Essaie D'expliquer la Formation des Ecailles de Poissons; Mémoires Académie des Sciences: Paris, France, 1716.

2. Ferchault de Réaumur, R.A. Idée Générale des Différentes Manières Dont on Peut Faire la Porcelaine et Quelles Sont les Véritables Matières de Celle de la Chine; Mémoires Académie des Sciences: Paris, France, 1727. 
3. Ferchault de Réaumur, R.A. Second Mémoire sur la Porcelaine ou Suite des Principes qui Doivent Conduire Dans la Composition des Porcelaines de Différents Genres et qui Etablissent les Caractères des Matières Fondantes Qu'on ne Peut Choisir Pour Tenir Lieu de Celle Qu'on Employe à la Chine; Mémoires Académie des Sciences: Paris, France, 1729.

4. Ferchault de Réaumur, R.A. Mémoire sur L'art de Faire une Nouvelle Espèce de Porcelaine par des Moyens Extrêmement Simples et Faciles ou de Transformer le Verre en Porcelaine; Mémoires Académie des Sciences: Paris, France, 1739.

5. Colomban, P. The Destructive/Non-Destructive Identification of Enameled Pottery, Glass Artifacts and Associated Pigments-A Brief Overview. Arts 2013, 2, 77-110. [CrossRef]

6. Sabbatini, L.; Van der Werf, I.D. (Eds.) Chemical Analysis in Cultural Heritage; Physical Sciences Reviews; Walter De Gruyter Gmbh: Berlin, Germany, 2020.

7. Janssens, K. Modern Methods for Analysing Archaeological and Historical Glass; John Wiley \& Sons Ltd.: Chichester, UK, 2013; Volume 2.

8. Richet, P. Encyclopedia of Glass Science, Technology, History, and Culture; Richet, P., Ed.; John Wiley \& Sons: Hoboken, NJ, USA, 2021; Volume 2.

9. Colomban, P.; Milande, V. On-site Raman analysis of the earliest known Meissen porcelain and stoneware. J. Raman Spectrosc. 2006, 37, 606-613. [CrossRef]

10. Colomban, P. On-site Raman identification and dating of ancient glasses: A review of procedures and tools. J. Cult. Herit. 2008, 9, e55-e60. [CrossRef]

11. Ricciardi, P.; Colomban, P.; Tournié, A.; Milande, V. Non-destructive on-site identification of ancient glasses: Genuine artefacts, embellished pieces or forgeries? J. Raman Spectrosc. 2009, 40, 604-617. [CrossRef]

12. Colomban, P. The on-site/remote Raman analysis with mobile instruments: A review of drawbacks and success in cultural heritage studies and other associated fields. J. Raman Spectrosc. 2012, 43, 1529-1535. [CrossRef]

13. Colomban, P. On-site Raman study of artwork: Procedure and illustrative examples. J. Raman Spectrosc. 2018, 49, 921-934. [CrossRef]

14. Vandenabeele, P.; Edwards, H.G.M.; Jehlička, J. The role of mobile instrumentation in novel applications of Raman spectroscopy: Archaeometry, geosciences, and forensics. Chem. Soc. Rev. 2014, 43, 2628-2649. [CrossRef]

15. Madariaga, J.M. Analytical chemistry in the field of cultural heritage. Anal. Methods 2015, 7, 4848-4876. [CrossRef]

16. Koleini, F.; Colomban, P.; Pikirayi, I.; Prinsloo, L.C. Glass Beads, Markers of Ancient Trade in Sub-Saharan Africa: Methodology, State of the Art and Perspectives. Heritage 2019, 2, 2343-2369. [CrossRef]

17. Shackley, M.S. Is there reliability and validity in portable X-ray fluorescence spectrometry (PXRF)? SAA Archaeol. Rec. 2010, 10, 17-20.

18. Liritzis, I.; Zacharias, N. Portable XRF of Archaeological Artifacts: Current Research, Potentials and Limitations. In X-ray Fluorescence Spectrometry (XRF) in Geoarchaeology, 1st ed.; Schackley, M.S., Ed.; Springer: New York, NY, USA, 2011 ; pp. 109-142.

19. Colomban, P.; Tournié, A.; Maucuer, M.; Meynard, P. On-site Raman and XRF analysis of Japanese/Chinese bronze/brass patina-The search for specific Raman signatures. J. Raman Spectrosc. 2012, 43, 799-808. [CrossRef]

20. Goodale, N.; Bailey, D.G.; Jones, G.T.; Prescott, C.; Scholz, E.; Stagliano, N.; Lewis, C. pXRF: A study of inter-instrument performance. J. Archaeol. Sci. 2012, 39, 875-883. [CrossRef]

21. Frahm, E. Validity of "off-the-shelf" handheld portable XRF for sourcing Near Eastern obsidian chip debris. J. Archaeol. Sci. 2013, 40, 1080-1092. [CrossRef]

22. Speakman, R.J.; Shackley, M.S. Silo science and portable XRF in archaeology: A response to Frahm. J. Archaeol. Sci. 2013, 40, 1435-1443. [CrossRef]

23. Forster, N.; Grave, P. Effects of elevated levels of lead in ceramics on provenancing studies using non-destructive PXRF: A case study in Byzantine Cypriot glazed ceramics. X-ray Spectrom. 2013, 42, 480-486. [CrossRef]

24. Liu, S.; Li, Q.H.; Fu, Q.; Gan, F.X.; Xiong, Z.M. Application of a portable XRF spectrometer for classification of potash glass beads unearthed from tombs of Han Dynasty in Guangxi, China. X-ray Spectrom. 2013, 42, 470-479. [CrossRef]

25. Brand, N.W.; Brand, C.J. Performance comparison of portable XRF instruments. Geochem. Explor. Environ. Anal. 2014, 14, 125-138. [CrossRef]

26. Hunt, A.M.W.; Speakman, R.J. Portable XRF analysis of archaeological sediments and ceramics. J. Archaeol. Sci. 2015, 53, 626-638. [CrossRef]

27. Fermo, P.; Andreoli, M.; Bonizzoni, L.; Fantauzzi, M.; Giubertoni, G.; Ludwig, N.; Rossi, A. Characterisation of Roman and Byzantine glasses from the surroundings of Thugga (Tunisia): Raw materials and colours. Microchem. J. 2016, 129, 5-15. [CrossRef]

28. Licenziati, F.; Calligaro, T. Study of mosaic glass tesserae from Delos, Greece using a combination of portable $\mu$-Raman and X-ray fluorescence spectrometry. J. Archaeol. Sci. Rep. 2016, 7, 640-648. [CrossRef]

29. Frahm, E.; Goldstein, S.T.; Tryon, C.A. Late Holocene forager-fisher and pastoralist interactions along the Lake Victoria shores, Kenya: Perspectives from portable XRF of obsidian artifacts. J. Archaeol. Sci. Rep. 2017, 11, 717-742. [CrossRef]

30. Stroth, L.; Otto, R.; Daniels, J.T.; Braswell, G.A. Statistical artifacts: Critical approaches to the analysis of obsidian artifacts by portable X-ray fluorescence. J. Archaeol. Sci. Rep. 2019, 24, 738-747. [CrossRef]

31. Simsek Franci, G. Handheld X-ray fluorescence (XRF) versus wavelength dispersive XRF: Characterization of Chinese blue-andwhite porcelain sherds using handheld and laboratoy-type XRF instruments. Appl. Spectrosc. 2020, 74, 314-322. [CrossRef] 
32. Demirsar Arli, B.; Simsek Franci, G.; Kaya, S.; Arli, H.; Colomban, P. Portable X-ray Fluorescence (p-XRF) Uncertainty Estimation for Glazed Ceramic Analysis: Case of Iznik Tiles. Heritage 2020, 3, 1302-1329. [CrossRef]

33. Simsek, G.; Arli, B.D.; Kaya, S.; Colomban, P. On-site pXRF analysis of body, glaze and colouring agents of the tiles at the excavation site of Iznik kilns. J. Eur. Ceram. Soc. 2019, 39, 2199-2209. [CrossRef]

34. Bezur, A.; Casadio, F. The Analysis of Porcelain Using Handheld and Portable X-ray Fluorescence Spectrometer. In Studies in Archaeological Sciences: Handheld XRF for Art and Archaeology; Shugar, A., Mass, J., Eds.; Leuven University Press: Leuven, Belgium, 2013.

35. Simsek, G.; Colomban, P.; Casadio, F.; Bellot-Gurlet, L.; Zelleke, G.; Faber, K.T.; Milande, V.; Tilliard, L. On-Site Identification of Early Böttger Red Stoneware Using Portable XRF/Raman Instruments: 1, Body analysis. J. Am. Ceram. Soc. 2014, 97, $2745-2754$. [CrossRef]

36. Simsek, G.; Colomban, P.; Casadio, F.; Bellot-Gurlet, L.; Zelleke, G.; Faber, K.T.; Milande, V.; Tilliard, L. On-Site Identification of Early Böttger Red Stoneware Using Portable XRF/Raman Instruments: 2, Glaze \& Gilding Analysis. J. Am. Ceram. Soc. 2015, 98, 3006-3013. [CrossRef]

37. Simsek, G.; Colomban, P. Portable XRF Study of Pottery: State of the Art and Perspective. In Proceedings of the TECHNART 2019-International Conference on the Use of Analytical Techniques for Characterization of Artworks, Bruge, Belgium, 7-10 May 2019; pp. 2-106.

38. Kingery, W.D. The development of European porcelain. In High-Technology Ceramics: Past, Present, and Future-The Nature of Innovation and Change in Ceramic Technology; Kingery, D.W., Ed.; Ceramics and Civilization Series; American Ceramic Society: Westerville, OH, USA, 1986; Volume III, pp. 153-180.

39. Finlay, R. The Pilgrim Art: Culture of Porcelain in World History. J. World Hist. 1998, 2, 141-187. [CrossRef]

40. Barber, E.A. So-Called "Red Porcelain", or Boccaro Ware of the Chinese, and its Imitations. Bull. Pa. Mus. 1911, 9, 17-23. [CrossRef]

41. Goder, W.; Schulle, W.; Wagenbreth, O.; Walter, H. Meissen, La Découverte de la Porcelain Européenne en Saxe; Böttger, J.F., Ed.; Pygmalion-Gérard Watelet: Paris, France, 1984.

42. Jouenne, M. Céramique Générale; Gauthier-Villard: Paris, France, 1959.

43. Haussone, M. Technologie Générale. Faïences, Grès, Porcelaines; Baillère: Paris, France, 1969.

44. Colomban, P.; Treppoz, F. Identification and differentiation of ancient and modern European porcelains by Raman macro- and microspectroscopy. J. Raman Spectrosc. 2001, 32, 93-102. [CrossRef]

45. Edwards, H.G.M. 18th and 19th Century Porcelain Analysis; A Forensic Provenancing Assessment; Springer: Cham, Germany, 2020; Available online: https:/ / www.springer.com/gp/book/9783030421915 (accessed on 15 December 2021).

46. Carty, W.M.; Senapatti, I. Porcelain-Raw materials, processing, phase evolution, and mechanical behavior. J. Am. Ceram. Soc. 1998, 81, 3-20. [CrossRef]

47. Iqbal, Y.; Lee, W. Microstructural evolution in triaxial porcelain. J. Am. Ceram. Soc. 2000, 83, 3121-3127. [CrossRef]

48. Sciau, P.; Loé, L.; Colomban, P. Metal nanoparticles in contemporary potters' master pieces: Lustre and red "pigeon blood" potteries as models to understand the ancient pottery. Ceram. Int. 2016, 42, 15349-15357. [CrossRef]

49. Ullrich, B. Vergleichende Untersuchungen an historischen deutschen und chinesischen Steinzeugen des frühen 18. Jahrhunderts. Silik. Tech. 1990, 41, 328-330.

50. Kockelmann, W.; Chapon, L.C.; Engels, R.; Schelten, J.; Neelmeijer, C.; Walcha, H.-M.; Artioli, G.; Shalev, S.; Perelli-Cippo, E.; Tardocchi, M.; et al. Neutrons in cultural heritage research. J. Neutron Res. 2006, 14, 37-42. [CrossRef]

51. Kockelmann, W.; Kirfel, A. Neutron diffraction studies of archaeological objects on ROTAX. Physica B 2004, 350, e581-e585. [CrossRef]

52. Schulle, W.; Goder, F.W. Die Erfindung des europaischen Porzellans durch Böttger—eine systematische schöpferische Entwicklung. Keram. Ztschr. 1982, 34, 598-600.

53. Swann, C.P.; Nelson, C.H. Böttger stoneware from North America and Europe: Are they authentic? Nucl. Instr. Meth. Phys. Res. B 2000, 161-163, 694-698. [CrossRef]

54. Schmidt, B.; Wetzig, K. Special Ion Beam Applications in Materials Analysis Problems. In Ion Beams in Materials Processing and Analysis; Springer: Vienna, Austria, 2013; pp. 377-411.

55. Anders, G.J.P.A.; Jörg, C.J.A.; Stern, W.B. On some physical characteristics of Chinese and European red wares. Archaeometry 1992, 34, 43-52. [CrossRef]

56. Brongniart, A. Traité des Arts Céramiques ou des Poteries Considérées dans leur Histoire, leur Pratique et leur Théorie, 3rd ed.; Asselin, P., Ed.; Libraire Faculté de Médecine: Paris, France, 1877; Volume 2.

57. Hall, G.E.M.; Bonham-Carter, G.F.; Buchar, A. Evaluation of portable X-ray fluorescence (pXRF) in exploration and mining: Phase 1, control reference materials. Geochem. Explor. Environ. Anal. 2014, 14, 99-123. [CrossRef]

58. Williams, R.; Taylor, G.; Orr, C. pXRF method development for elemental analysis of archaeological soil. Archaeometry 2020, 62, 1145-1163. [CrossRef]

59. Fornacelli, C.; Volpi, V.; Ponta, E.; Russo, L.; Briano, A.; Donati, A.; Giamello, M.; Bianchi, G. Grouping Ceramic Variability with pXRF for Pottery Trade and Trends in Early Medieval Southern Tuscany. Preliminary Results from the Vetricella Case Study (Grosseto, Italy). Appl. Sci. 2011, 11, 11859. [CrossRef] 
60. XRF Background Notes. Available online: http:/ / cais.uga.edu/wp-content/uploads/2019/01/XRF_Background.pdf (accessed on 19 December 2021).

61. Edwards, H.G.M. Porcelain Analysis and Its Role in the Forensic Attribution of Ceramic Specimens; Springer: Cham, Switzerland, 2022. 